\title{
PALE SHelter, Cold HANDS: MAKING CRIMINAL JUSTICE BETTER
}

\author{
Yvette Tinsley*
}

In memory of Mona. ${ }^{1}$

\section{INTRODUCTION}

Thank you to the Vice-Chancellor for his kind introduction. It's lovely to see so many family, friends and colleagues here this evening: thanks to all of you for giving your time. Although it's often said that an inaugural lecture is a difficult beast (and it really is), it's a wonderful opportunity for me to speak to my children when it's difficult for them to leave the room! There are some notable absences tonight. My parents, sister, nephew and extended family are in the United Kingdom, unable to travel here because of the pandemic. In lieu of them being here in person, the title of this lecture includes a little homage to my parents and their tolerance of my teenage habit of pencilling song lyrics over every visible square inch of my bedroom walls. Those who know me well will not be surprised by this - many current and former students have been subjected to my post-punk, New Wave song lists that "fit" with criminal justice and criminal law. For that, I apologise, but doubt that the behaviour will change any time soon.

It is perhaps fitting, therefore, that the title of my lecture is an adaptation of a song lyric that evokes for me the current failings of the criminal justice process. The song, by a band called Tears for Fears, was named after Henry Moore's Pale Shelter Scene drawing from 1941. ${ }^{2}$

* Professor of Law, Faculty of Law, Victoria University of Wellington | Te Herenga Waka.

1 This article is a very lightly edited and referenced version of my professorial inaugural lecture, which took place on 4 May 2021. A recording of the lecture is available at: Yvette Tinsley "Pale Shelter, Cold Hands: Making Criminal Justice Better" (inaugural lecture, Victoria University of Wellington | Te Herenga Waka, 4 May 2021) <https://www.wgtn.ac.nz/events/2021/05/inaugural-lecture-by-yvette-tinsley>.

2 See figure 1 below. 
Figure $1:^{3}$

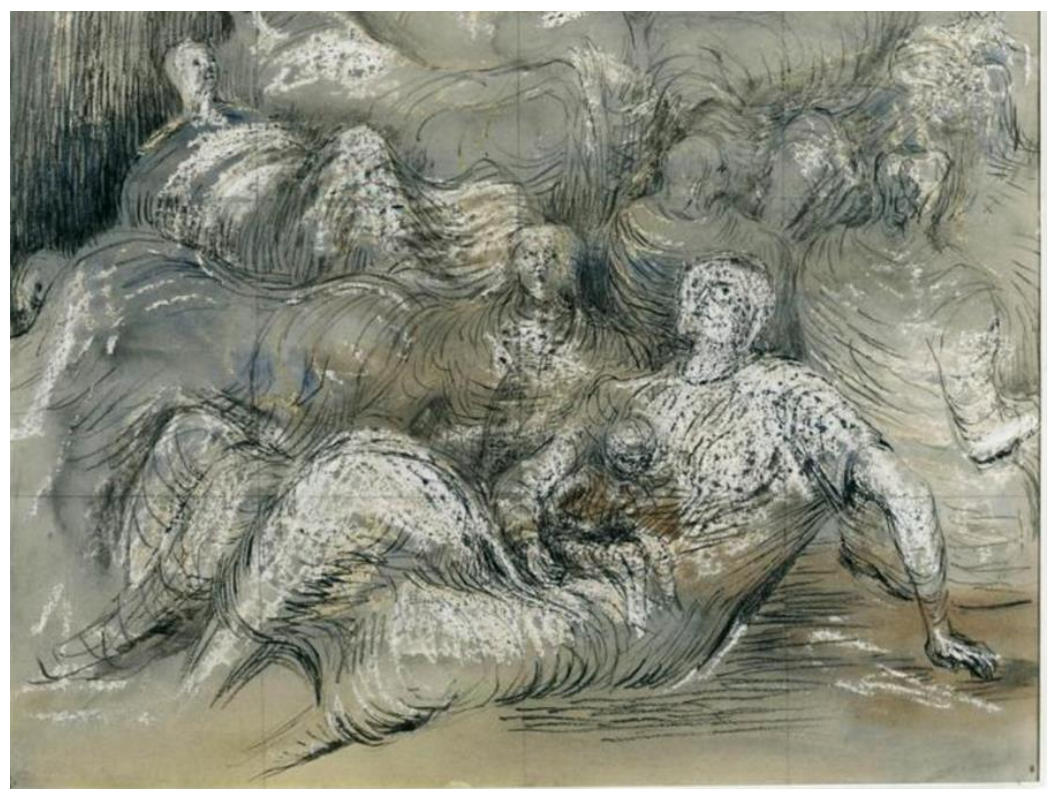

The drawing is a bleak depiction of people coming together to avoid harm from enemy bombing "like the chorus in a Greek drama telling us about the violence we don't actually witness." 4 Despite tales of camaraderie, we know that the shelters were full of "suffering humanity": 5 there was often overcrowding, illness and harm committed by fellow occupants. Moore likened the shelters to the hold of a slave ship "full of hundreds and hundreds of people who were having things done to them which they were quite powerless to resist". ${ }^{6}$ That sounds familiar as an experience of the criminal law.

3 Henry Moore, Pale Shelter Scene, 1941.

4 Henry Moore and Francis Carey (ed) Introduction to A Shelter Sketchbook (British Museum Publications, London, 1988) at 9.

5 Geoffrey Field "Nights Underground in Darkest London: The Blitz, 1940-1941" (2002) 62 International Labor and Working-Class History 11 at 35. See also David Ashford "Children Asleep in the Underground: The Tube Shelters of Brandt and Moore" (2007) 36 The Cambridge Quarterly 295.

6 At 33 . 
The Tears for Fears "Pale Shelter" song goes on to lament that instead of love they are given not only pale shelter but also cold hands. ${ }^{7}$ In its attempt to be objective and stand back from the emotion of criminal cases, the criminal law - in my view - most definitely has icy cold hands.

Tonight then, I want to start by unpacking the idea of criminal law and justice as a pale shelter, looking at how it creates harm and dehumanises while it adjudicates and punishes on behalf of the community. The ill effects of the criminal justice process for victims and defendants, particularly for Māori and Pacific peoples, are well-established in New Zealand. ${ }^{8}$ As legal reform efforts have obviously and rightly focused on victims and defendants, I'll start there. But tonight, I won't spend all our time talking specifically about the harms caused to defendants and complainants by the criminal process. These are well documented and understood, for the most part. Instead, I'll spend some time illustrating that the harms of the criminal process reach everyone involved - there's a growing body of research, including a project I've just begun with Nichola Tyler from the School of Psychology, that shows the harmful emotional impacts on both lay people and criminal justice professionals. ${ }^{9}$

Having highlighted some of the ways in which the criminal process causes more harm by attempting to be unemotional, I'll say a little about why I think we haven't properly addressed or even recognised some of these problems in the criminal justice process. While we have some high-level recommendations from recent reports, ${ }^{10}$ I'll talk about the fact that we're stuck in a particular type of approach to criminal law reform and that reform efforts are largely siloed from other matters of social justice. It's therefore unsurprising to me that we have made little progress in addressing criminal law and justice problems.

Then finally to the hard part! I'll finish off the lecture tonight by talking about what I see as some viable steps towards making a change and how we can build on some initiatives that have already begun: how do we warm up those cold hands of the criminal law and make the criminal justice process a proper shelter where people can trust that harms will be responded to safely?

7 For the official video of the song, see Tears for Fears "Pale Shelter" Youtube <https://youtu.be/BUfcT5OoP$8>$.

8 Some of the scholarly work, statistics and government reports regarding the impacts of criminal justice processes on defendants and victims were brought together for the government initiative Hāpaitia te Oranga Tangata: Safe and Effective Justice (for reports and resources, see <www.justice.govt.nz>).

9 Yvette Tinsley and Nichola Tyler "Criminal lawyers are regularly exposed to trauma - how can NZ's justice system look after them better?" (13 September 2021) The Conversation 〈https://theconversation.com〉.

10 See for example Te Uepū Hāpai i Te Ora Safe and Effective Justice Advisory Group Turuki! Turuki! Move Together: Transforming our criminal justice system (2020); Hui Māori Ināia Tonu Nei (July 2019); and Chief Victims Advisor to Government Strengthening the Criminal Justice System for Victims: Workshop Playback Report (August 2019). 


\section{COLD HANDS DON'T MAKE FOR A WARM HEART: CAUSING HARM WHILE RESPONDING TO HARM}

Criminal law is about people's stories, their histories. For that reason, I'll start by sharing what motivates me, and one of my own stories.

Most of my formative years were in the Thatcher era. I lived in a mining village, and as a school student during the miners' strike in the mid-1980s, I saw the impact of police misuse of power on the picket lines. This included Metropolitan Police officers beating striking miners in Nottinghamshire and then issuing them with "I've met The Met" stickers, and the same officers stealing souvenirs from miners and coal yards. ${ }^{11}$ Later, when I was a student, I attended the Freedom to Party rally to protest government efforts to end acid house parties (yes, the right to party had a real rally, it was not just a Beastie Boys song), and at poll tax and student loan demonstrations, I experienced the violence involved in the policing of public protests for myself. ${ }^{12}$

When I think about my research life, seemingly disparate projects I've worked on from eyewitness identification, through sexual violence reform, evidence law reform, juries, and sentencing, can all be linked by a motivation to improve the experience that people have with the criminal justice process that stems back to the unfairness I saw when I was young. Those early experiences sowed the seeds for the research I do, the questions I want to ask, and ultimately, my ideas about reform of the criminal justice process.

I've been lucky enough to be involved in some projects that have led to legislative reform, but I've learned that policy and practice change are just as - and sometimes more - influential. I'm a sociolegal researcher, a term that isn't easy to define because it means different things to different people. But at its most basic, it means that I take a multi or inter-disciplinary approach to the study of legal phenomena, using both theoretical and empirical methods. For legal academics like me then, theoretical perspectives and methodologies are informed by research undertaken in disciplines outside law as well as by traditional legal research and theory.

Of all the branches of law, criminal law is where the power of the state is the most visible. Ultimately, decision-making in the criminal justice process can deprive people of their liberty. The criminal justice process causes harm while it is responding to harm. I'm not referring here to harm in

11 Harry Paterson Look Back in Anger: The Miners' Strike in Nottinghamshire 30 Years On (Five Leaves, Nottingham, 2014). The most famous example of brutality against striking miners was perhaps at Orgreave: David Waddington "The battle of Orgreave: Afterword" in Ra Page (ed) Protest: Stories of Resistance (Comma Press, Manchester, 2017) 366; and David Conn "The Scandal of Orgreave" The Guardian (online ed, Manchester, 18 May 2017) <www.theguardian.com>.

12 "In January 1990, the Freedom to Party Rally took over Trafalgar Square ..." (2020) 909 Originals <https://909originals.com>; and "On this Day: The Times, November 25, 1988" The Times (online ed, London, 25 November 2002) <www.thetimes.co.uk>. 
the sense of "violation of a person's interest", as is required for criminalisation, ${ }^{13}$ but in the general sense of physical or psychological harm caused by some loss.

For me, the idea of criminal justice as something harmful that is experienced, as something that happens to people, something that is intensely personal and emotional, started even before the miners' strike and rallies to preserve my ability to attend raves. It started with family stories about the $1930 \mathrm{~s}$ kidnapping and murder of my grandfather's cousin, Mona, when she was 10 years old. ${ }^{14}$

Figure $2:^{15}$

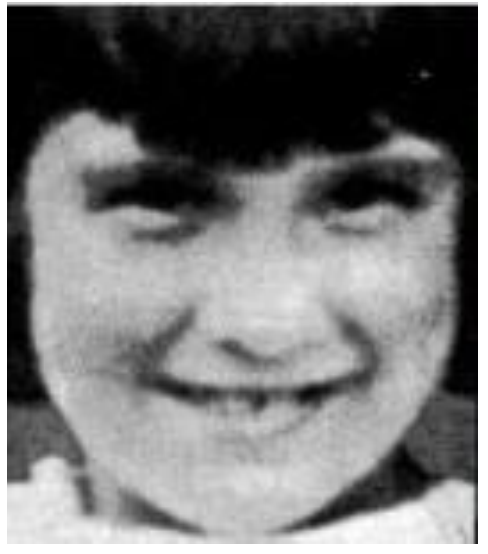

The stories focused on the family's frantic search for Mona (and later for her body) over days and weeks and months, the sense of loss and panic, and the momentous impacts it had on extended branches and future generations of the family.

13 For a modern take on the harm principle and criminalisation, see AP Simester and Andreas von Hirsch Crimes, Harms, and Wrongs: On the Principles of Criminalisation (Hart Publishing, Oxford, 2014).

14 Winifred Duke The Trials of Frederick Nodder: The Mona Tinsley Case (Hodge, London, 1950).

15 Mona Tinsley. This photograph appeared in news reports about Mona's disappearance. 
Figure 3:16

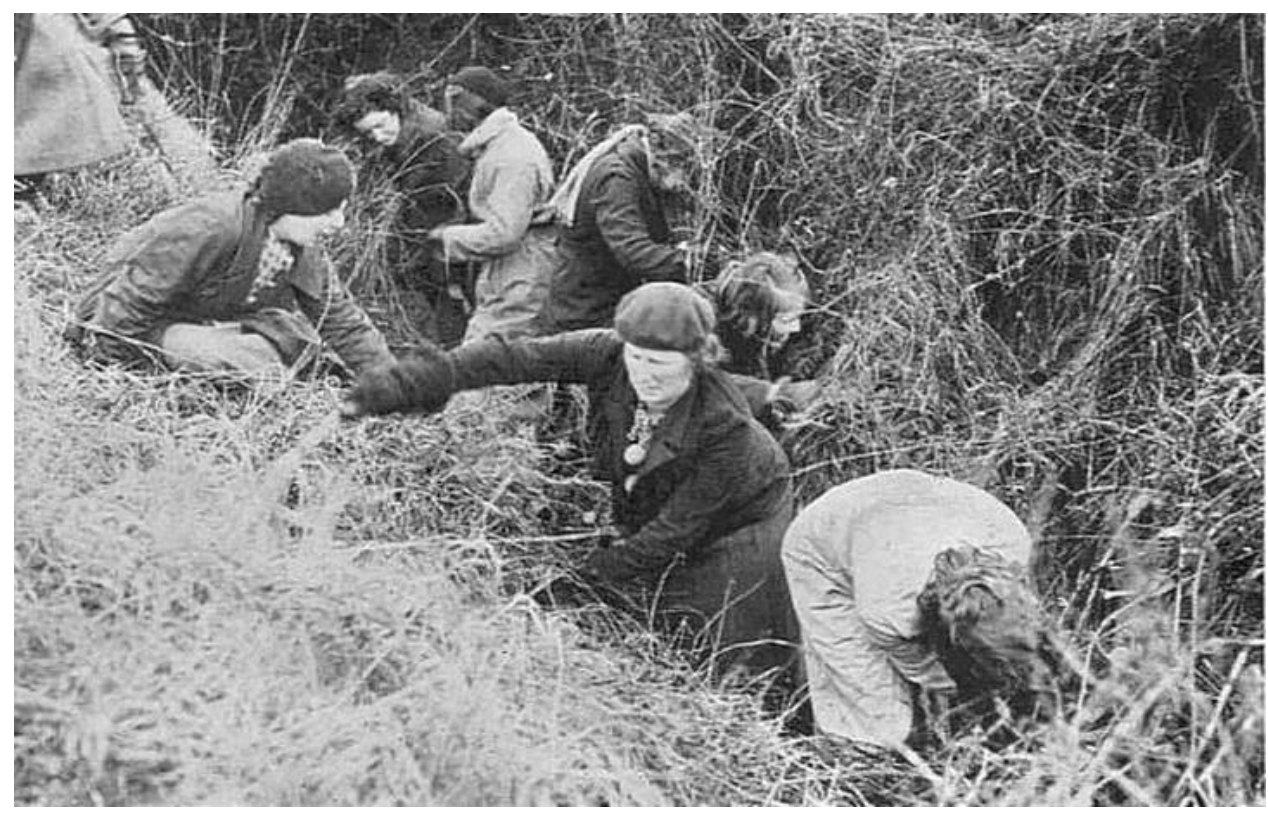

Later, I read about Mona's case - several books and articles have been written about it, often in the 1960s style of reporting on true crime, but also including news reports as late as $2020 .{ }^{17}$ The case was notorious and was important as one of the last "no body, no murder" cases. ${ }^{18}$ It has prompted blogs, Pinterest posts and even a music recording. ${ }^{19}$ It went to two trials, the first for kidnapping and the second for murder when Mona's body was eventually found in a river. Mona's funeral was so wellattended it virtually closed her home town, and a small monument was erected, such was the contemporary national - and international - interest in the disappearance and subsequent trial. But because to me the case is personal, what affected me most was the suspicion cast on her family and the blame placed on her parents for being ineffectual, essentially because they were poor and uneducated. That to me was a message about the criminal law that went beyond the intellectual and legal aspects of the case (even though those fascinated me later) - it was the human element, the

16 This photograph is titled "Locals Searching for Mona".

17 Duke, above n 14; James H Hodge Famous Trials: Sixth Series (Penguin, Harmondsworth, 1994); and Andy Done-Johnson "The unusual story of the Sheffield man tried twice for the murder of a 10-year-old girl" The Star (online ed, Sheffield (UK), 17 July 2020) <www.thestar.co.uk>.

18 Greig Watson "The mother, the medium and the murder that changed the law" (5 January 2017) BBC News <www.bbc.com>.

19 The Need "Mona Tinsley" on The Need is Dead (2000). 
emotion, and the ongoing inter-generational pain that resonated first. Public interest was prurient - no body, a psychic medium employed in the search, and tales of infidelity. ${ }^{20}$ Police and the courts were distant and aloof for Mona's family - officialdom that unemotionally handled a part of their profound grief. The criminal law and its agents had cold hands indeed.

\section{A Criminal Justice Gives Pale Shelter to Defendants and Complainants}

It is too easy to forget that people involved in a criminal case are more than the moment of offending. People come into the criminal process with complete life histories and full stories. And as I look at the criminal justice process today, their treatment is not much better than my family suffered at the time of Mona's disappearance. Those living in poverty are still more likely to be offenders, more likely to be victims, and more likely to be blamed for what happens to them. ${ }^{21}$ In Aotearoa New Zealand, because of a colonial taking of political power, they are also more likely to be Māori. ${ }^{22}$ It is apparent then that the criminal justice process harms some more than others.

Much criminal justice research understandably focuses on the inequities of the criminal process for suspects, defendants and offenders. New Zealand has an adversarial criminal justice process, whereby parties put forward competing narratives about what the truth is, and the prosecution must prove the case against the defendant beyond reasonable doubt, a term that continues to confuse law students and juries alike. ${ }^{23}$ Unlike civil law jurisdictions, such as those in continental Europe, the parties decide what witnesses to call and the judge acts as an impartial referee. ${ }^{24}$

While the trial is touted as the ultimate focal point, in reality, most criminal offences don't go to a defended trial, much less a jury trial. ${ }^{25}$ Most defendants are dealt with in a way that is much more perfunctory than popular culture would have us believe. Along the way, there are incentives to plead guilty, both explicit (for example, a guilty plea discount) and implicit (for minor offending, it can seem easier to plead guilty to "get it over with"). "Getting it over with" is an understandable aim when,

20 Watson, above n 18

21 In common with international literature, those with low household incomes are more likely to be victims of crime in New Zealand and are also more likely to offend: Ministry of Justice New Zealand Crime and Victims Survey: Highly Victimised People (Topical Report, 2018); and Sheree J Gibb, David M Fergusson and L John Horwood "Childhood family income and life outcomes in adulthood: Findings from a 30-year longitudinal study in New Zealand' (2012) 74 Social Science \& Medicine 1979.

22 Kim Workman and Tracey McIntosh "Crime, Imprisonment and Poverty" in Max Rashbrooke (ed) Inequality: A New Zealand Crisis (Bridget Williams Books, Wellington, 2013) 127.

23 See for example Jonathan Clough and others "The Judge as Cartographer and Guide: The Role of Fact-based Directions in Improving Juror Comprehension" (2018) 42 Crim LJ 278 at 281.

24 John R Spencer "Adversarial vs inquisitorial systems: is there still such a difference?" (2016) 20 IJHR 601 at 610 .

25 Jury trials are reserved for Category 3 and 4 trials: see for example the Criminal Procedure Act 2011, ss 6, 50 and 74. 
to use Malcolm Feeley's famous phrase, the "process is the punishment". ${ }^{26}$ In his book, Feeley reveals the multitude of decisions made before a defendant is ever presented in court, and how the process itself can be "dirty and hurried". ${ }^{27}$ The phrase has come to denote the problem that, from the very first connection with the criminal process, defendants' lives are impacted, not only in ways directly related to decision-making about their alleged offending: employment can be affected, relationships, reputation and so on - often before adjudication takes place by way of a guilty plea or defended trial.

In terms of imprisonment rates and sentence lengths, New Zealand can be described as punitive. Our imprisonment rate is approximately 164 per 100,000 of the population. ${ }^{28}$ Although this is much improved from three years ago when the rate was 214 per 100,000 of the population, it still puts us in the top half of OECD countries (it's not a list we want to top). ${ }^{29} \mathrm{We}$ have one of the higher percentages of sexual and violent prisoners, possibly due to sentence lengths rather than offending patterns. ${ }^{30} \mathrm{As}$ a point of reference, England and Wales currently has an imprisonment rate of 132 per 100,000 of the population and Nordic countries, Germany and the Netherlands have rates around 60 per 100,000. ${ }^{31}$ Our remand population (prisoners who have not yet been tried) is 61 per 100,000, which is 37 per cent of the prison population. ${ }^{32}$ We imprison people who have not yet been convicted at a higher rate than some countries imprison full stop. So Feeley's idea of the process being the punishment still rings true in modern-day New Zealand.

It is now well known and accepted that Māori suffer these ill effects of the criminal justice process more than any other group in New Zealand. They are over-represented in criminal statistics from arrest through to imprisonment, including remand in custody. ${ }^{33}$ The harms are undeniable: Māori comprise just under 17 per cent of the general population, but approximately 53 per cent of the prison

26 Malcolm M Feeley The Process is the Punishment: Handling Cases in a Lower Criminal Court (Russell Sage Foundation, New York, 1979).

27 Jennifer Earl "The Process Is the Punishment: Thirty Years Later" (2008) 33 Law \& Social Inquiry 737 at 737.

28 Based on figures from end of June 2021, sourced from the World Prison Brief: "New Zealand" World Prison Brief, Institute for Crime and Justice Policy Research <www.prisonstudies.org>.

29 "Highest to Lowest - Prison Population Rate" World Prison Brief, Institute for Crime and Justice Policy Research <www.prisonstudies.org>

30 Marcus Boomen "Where New Zealand stands internationally: A comparison of offence profiles and recidivism rates" (2018) 6(1) Practice: The New Zealand Corrections Journal 87.

31 "Highest to Lowest - Prison Population Rate", above n 29.

32 "New Zealand", above n 28; and "Prison Facts and Statistics - June 2021" (30 June 2021) Department of Corrections <www.corrections.govt.nz>.

33 Eleanor Brittain and Keith Tuffin "Ko tēhea te ara tika? A discourse analysis of Māori experience in the criminal justice system" (2017) 46(2) New Zealand Journal of Psychology 99. 
population. ${ }^{34}$ The impacts of colonisation and the loss of Māori political power are very much present in our criminal justice process today. ${ }^{35}$ Over-representation is no longer shocking, and the responsibility of the state and its successive governments for ongoing structural disadvantage is often underplayed in favour of reforms that place responsibility on perceived individual and group "deficits". ${ }^{36}$ Harms to whānau continue despite promises of reform.

My own early motivations, interests and reform plans revolved solely around addressing the harms I saw suspects, defendants and offenders suffering because the process didn't work properly. But my experience as a survivor of crime when I was a postgraduate student made me broaden my scope. It was a good life - and research - lesson in the harms the criminal process inflicts on victims of crime. I was not kept well-informed by Police or the prosecution. I was shocked on the day of the trial to find out that charges had been amended in order to bargain a guilty plea; and even though I expected it, I was upset later that I had to hear pleas in sentencing submissions that were distortions of the truth, with no way for me to respond. Even knowing the system as I did, having worked in criminal defence and knowing prosecutors, I wasn't expecting to feel quite so much of an outsider to proceedings about harm that had happened to me.

My experience was over 25 years ago in the United Kingdom. Yet it doesn't take much to see that the experience of victims today in New Zealand is still poor. ${ }^{37}$ Victims put trust in the criminal justice process and the people working within it. But within an adversarial process, victims are not parties to the offence. While there is a common perception that our criminal justice process is highly individualised (and it is true that we emphasise individual procedural rights), a criminal prosecution is ultimately a communal process in the sense that the state represents the community, not an individual. While this is intended to relieve victims of the burden of bringing actions for harms committed against them, its result is - as legal scholar Andrew Ashworth coins it - that as far as the adversarial system is concerned "the victim's interest is surely no greater than yours or mine". 38

34 "Prison Facts and Statistics - June 2021", above n 32.

35 Moana Jackson The Māori and the Criminal Justice System: A New Perspective - He Whaipaanga Hou, part 2 (Department of Justice, Study Series 18, Research Report, November 1988).

36 Elizabeth Stanley and Riki Mihaere "Managing Ignorance About Māori Imprisonment" in Alana Barton and Howard Davis (eds) Ignorance, Power and Harm: Agnotology and The Criminological Imagination (Palgrave Macmillan, Cham (Switzerland), 2018) 113.

37 Chief Victims Advisor to Government, above n 10; and Chief Victims Advisor to Government Strengthening the Criminal Justice System for Victims: Survey Report (August 2019).

38 Andrew Ashworth "Responsibilities, Rights and Restorative Justice" (2002) 42 Brit J Criminol 578 at 585. 
Meanwhile, communities that suffer other forms of social injustice are over-represented as victims and as repeat victims. ${ }^{39}$ Māori in particular are overrepresented as victims of violent offending. ${ }^{40}$ Reporting rates for violent crime, particularly of sexual violence, are low. ${ }^{41}$ Reforms to "victims' rights" legislation have tended to merely pay lip-service while making little appreciable difference to the actual experience of victims in the process. This has all been exacerbated by the tendency to cast victims and offenders as two disparate groups - yet not only do victims and offenders both come from our community, they are often the same people. ${ }^{42}$ If ever a shelter was pale, it is the one provided to victims of crime.

While the harms caused to defendants and complainants by the process are well-researched, my argument is that the harms inflicted by the process - by the way we do justice - go well beyond this.

\section{B No One is Given Warm Hands}

We know that the effects of criminal process itself, as well as the offending behaviour, ripple out to whānau and beyond. But what is less well-documented is the impact of the process on other actors within it. While most research focuses on the dehumanising effects for victims and defendants, there is nonetheless a growing international body of research that shows both positive and negative emotional impacts for others in the process, including judges, lawyers, Police and other criminal justice professionals. I want to briefly illustrate this by looking at two groups that I have had the privilege of researching - jurors and prosecutors.

\section{Jurors: "There were a lot of tears in the room"}

There is little research internationally on the impacts of criminal justice on jurors - we are one of the few countries in the world that has had large-scale qualitative studies with jurors in real trials. I have had the pleasure of being involved in the two largest studies. ${ }^{43}$ When I first came to New

39 Ministry of Justice New Zealand Crime and Victims Survey: Highly Victimised People, above n 21.

40 Ministry of Justice New Zealand Crime and Victims Survey: Māori Victimisation in Aotearoa New Zealand (Topical Report, 2019); and Robert Webb "Māori Experiences of Colonisation and Māori Criminology" in Antje Deckert and Rick Sarre (eds) The Palgrave Handbook of Australian and New Zealand Criminology, Crime and Justice (Palgrave Macmillan, Cham (Switzerland), 2017) 683; and Brittain and Tuffin, above n 33.

41 Ministry of Justice What NZCVS Means to a Village: Cycle 2 Infographic (2020 Wellington); and Ministry of Justice New Zealand Crime and Victims Survey: Key findings - Descriptive statistics (June 2021).

42 Lily George and others "Narratives of Suffering and Hope: Historical trauma and contemporary rebuilding for Māori women with experiences of incarceration" (2014) 3 MAI Journal 183. See also Andrew Sanders, Richard Young and Mandy Burton Criminal Justice (4th ed, Oxford University Press, New York, 2010).

43 For example, see Warren Young, Neil Cameron and Yvette Tinsley Jury Trials in New Zealand: A Survey of Jurors (New Zealand Law Foundation Research Report, 1999); Law Commission Juries in Criminal Trials Part Two: A summary of the research findings (NZLC PP37, 1999); Yvette Tinsley, Claire Baylis and Warren Young "'I Think She's Learnt Her Lesson': Juror Use of Cultural Misconceptions in Sexual Violence Trials" 
Zealand, I was warned by my PhD supervisor and mentor, Professor John Baldwin, that I was coming to a "wasteland" for criminal justice scholars because New Zealand had very little crime. I have not found that to be a problem! I was very fortunate that Warren Young and Neil Cameron were here: I feel lucky to have come to a place where applied criminal justice research was taking place in the law school (and of course, lots was being done by colleagues, such as Professor Jan Jordan, at the Institute of Criminology too). Without Warren and Neil, it would have been difficult for me to follow my passion of socio-legal empirical research on any large scale. I learned a lot working with them on the first New Zealand jury study, and I confess to a warm feeling when Professor Baldwin - who is a renowned juries researcher himself - ended up being quite jealous that I was able to conduct research that was prohibited in England and Wales. ${ }^{44}$

Many jurors enjoy the experience of being on a jury, but a significant minority are emotionally impacted in ways that disturb their wellbeing, family life and work. What we have been told by jurors illustrates that the harms caused by the criminal justice process are not confined to victims and defendants. Some of the emotional harm is unavoidable - but how it is responded to and the extent to which it is disruptive of jurors' lives is something the criminal justice process can do something about.

Because I don't have much time this evening, I want to just give a brief snapshot of three aspects of juror stress and emotional harm:

(a) An emotionally draining and upsetting experience

First, many jurors - even those who are positive about the experience - talked about how draining and emotionally tiring the process is, and reported times of emotional release:

You almost feel like a victim. It was really stressful, intense and scary. I couldn't stop thinking about it and because you are instructed not to talk to anyone about it you can't deal with it.

Quite an emotional thing. Coming out on the Friday, when we had finished, I met my wife at the pub, and when I was waiting for her I was shaking.

Many suffered sleepless nights during and after the trial, and for a significant minority the effects lasted quite a time after the trial, their inability to "let it go" causing stress in their relationships:

[I had] an argument with my partner the first night because he thought I was ridiculously upset. He couldn't understand it at all ... The following day I found out most of the women went home and burst into tears.

(2021) 52 VUWLR 463; Benjamin Spivak and others "The Impact of Fact-Based Instructions on Juror Application of the Law: Results from a Trans-Tasman Field Study" (2020) 101 Social Science Quarterly 346; and Jonathan Clough and others, above n 23.

44 Juries Act 1974 (UK), s 20D. 
Upset and distress is often more acutely felt in violence and sexual violence trials, but can also manifest in other types of case, particularly longer trials, where jurors felt they made connections with people to be "just thrown out at the end".

Jurors not only find the evidence itself upsetting, but also the stress of deliberations and dealing with their fellow jurors. Some jurors cried during interviews recalling exchanges with other jurors and the tension in the jury room.

(b) Pressure to reach the "right" verdict

That tension relates to a second aspect of emotional harm and stress. Jurors can become distressed by the pressure to reach a "correct" verdict, and the impact of their decision on the lives of defendants, complainants and their whānau:

All of a sudden I thought, when I was sitting in the jury box, I had to decide someone's fate. I didn't know how overwhelming that would be.

I never want to go through it again ... I never want to have it on my shoulders to put a guy away ... We were all in tears ... [I was] physically ill.

And in a murder case:

We got back into the jury room after he [the judge] handed down the life sentence and twelve people, there was just not one word, just dead silence ... A couple of women cried, I cried when I got home. I drove [male juror] home and he had a cry on the way home ... It was pretty emotional for everybody.

(c) Jurors' own trauma is triggered

Pressures about the verdict are exacerbated when members of the jury are affected by evidence because of what they or someone close to them has experienced. Our studies suggest this is most likely to happen in sexual violence trials. As well as the personal impact on individual jurors, in a small minority of cases it can be disruptive of juror decision-making:

For most of the time she did not sit at the table with the other jurors, and at one stage she curled up in the corner in a foetal position.

\section{Prosecutors: "it's just endless suffering really for everyone"}

So far, I've looked at the harmful impacts of the criminal process on lay people. There is a growing body of research about the impacts of emotional labour and vicarious trauma on the wellbeing of those working in the criminal justice process. But there is very little New Zealand scholarship about it. Nichola Tyler and I are quite excited about our current study, which in the first phase examines prosecutors and defence counsel's experiences. Thanks to Nichola and to Rachel Kim, who conducted interviews with prosecutors for her MSc thesis research, for agreeing to let me share some quotes with you. The data is rich, so again I'll only share a small taster. 
First, almost all prosecutors told us that they felt the need to switch off their emotions. When asked "do you feel that there are certain emotions you're expected to perform as a Crown prosecutor?", one prosecutor said:

$\mathrm{Hmm}$, if detachment is an emotion ... fabricating emotion that otherwise doesn't exist. I feel more often my job calls on me to hold back something that I naturally feel.

You can't be emotive as a prosecutor, you can't cry, you can't get angry, you have to be completely lacking in emotion. Which, I don't know, I guess it's an emotion but ... devoid of emotion is the emotion you have to be.

Secondly, this need to work without being impacted emotionally fed into a sense that to feel emotion or admit to needing support was "weak" or showed they were not up to the job. This understandably seems to impact junior prosecutors the most:

Some of the older partners can't see why we're not tough enough.

I felt all the weight of my bosses telling me and my colleague 'it shouldn't matter to you that much', 'don't let it get to you'.

You definitely couldn't tell them [the senior partners] that you were depressed that's for sure. You can't afford to be worried about yourself when you've got all those other people to worry about.

As you can start to see from these quotes, it appears that the culture of firms, and the profession more generally, help to create the feeling that to have career advancement you should not show "weakness":

[It was suggested to] one of my co-workers the best way to get over her three rape trials in a row was to have a stiff glass of wine, which I think wasn't what she needed to hear at that time.

There is very much an expectation that you'll just get on with it and you can't be weak or fallible really. I don't think that you would advance professionally in the firm if you were to admit to being damaged. I mean it's okay to joke about it but not to seriously admit to the effect the material has on you ... It's implicit in that no-one's ever said don't ever tell us if you have a problem. But ... there's a lot of taking the piss out of anyone that does admit to being vulnerable so it's very clear that you wouldn't do that and still be held in high regard. [The people 'taking the piss' were the partners]

There was low enthusiasm amongst the prosecutors we've spoken to so far for EAP and Law Society advice lines, and they reported barriers to confidentially accessing other counselling through their firms:

The constant having to push was wearing me down. I'd rather go and pay for it myself.

There's this new service but it's not encouraged. Certainly not encouraged ... they started offering clinical psychologists that you can go to, but it's been described as the last cab in the rank kind of service ... we should be front footing these issues because a lot of the things I've said to you now, I know saying it out 
loud, that's not right and I shouldn't be thinking like that and ... I know a lot of people would be horrified if they found out the prosecutor was thinking things like I've said.

Thirdly, the role itself impacts prosecutors' wellbeing, leading to coping mechanisms such as dark humour or excessive drinking. These findings are reminiscent of international research conducted with police officers over the last 30 years or more. ${ }^{45}$ Prosecutors in our study reported that:

I feel like I'll never be able to be just a normal person after reading all this stuff. You just can't, you just cannot ... so much stress. You can't eat properly, you can't sleep properly, yeah. It's a bit of a nightmare if I'm honest.

You are exposed to a lot of trauma and you just do kind of push it aside till it becomes too much and you can't cope.

People just going off and are crying in the bathrooms. Or being very upset in the offices.

This included impacts on relationships:

Prosecuting sexual violence affects my life. If I'm in trial or the lead up to a trial, my job is to vividly paint a picture of sexual violence. My head is busy trying to recreate a picture of sexual violence ... And it's stewing over that in my subconscious and there is no way I've found to be physically intimate with my partner ... I just don't want my husband, I don't want to be half-way through having sex and suddenly my mind draw up the image from $2 \mathrm{pm}$ today of sexual violence ...

And a general sense of paranoia or suspicion:

[at a campsite on holiday] Do you think those girls are safe with their dad? Why are they just with their dad? Where's their mum? What could be happening in that tent right now? ... when I've woken up in the night, I've thought is there someone in the house? Could someone come in the house? There could be someone going to do a burglary. There could be someone coming in to look for a woman to rape ... it's a fear or an anxiety that I never had before.

The sort of like simple innocence is gone. So like before you know, I used to drive past camp grounds at the beach or people camping at the beach and think, oh great. These people are having a nice holiday. And now I drive past a campground and I think, there's definitely going to be at least ten kids getting molested in there ... And the people who are committing the offending, there's no way to know what they look like or no way to know who you should be suspicious of and not, so you just end up being suspicious of everybody unfortunately.

45 See for example Roger Graef Talking Blues: The Police in Their Own Words (Harper Collins, London, 1990); and Elizabeth Velazquez and Maria Hernandez "Effects of police officer exposure to traumatic experiences and recognizing the stigma associated with police officer mental health: A state-of-the-art review" (2019) 42 PIJPSM 711. 
I should make it clear that I'm not suggesting we could or should attempt to make the vicarious trauma and emotional labour of working in the criminal justice process magically go away. The point is that we are not addressing it in healthy ways, and therefore, the process is more harmful than it needs to be. The problems prosecutors identify here are mainly ones of harms caused by suppression of emotional response. Working in the criminal process will always expose people to vicarious trauma and require emotional labour. But that doesn't have to be unrelentingly harmful and negative in the way these prosecutors describe it. Acknowledging emotional impacts and supporting people to get help - for example through professional supervision - can actually lead to positive impacts. Psychological research shows that there are possible positive outlets for emotional labour, and that if harnessed, it can sometimes help people to do their jobs well and do them safely. ${ }^{46}$

\section{WHY HAVEN'T WE PUT THE HEATING ON? THE LIMITATIONS OF THE LEGAL REFORM MODEL}

What these examples of the harmful impacts of the criminal justice process illustrate is a form of dehumanisation - a disconnect between the law, the human beings that inhabit the criminal justice process, and wider society. In turn, this suggests that, while important, changes to the law alone will not fix the failings of the system.

In the early 1990s, I was studying at Birmingham law school, perhaps the best place in the United Kingdom for someone interested in criminal justice to be at that time. The Birmingham school was a powerhouse of empirical, socio-legal, and critical criminal justice research. And around the time the Birmingham Six conviction was famously quashed, it was a site of fruitful police research. ${ }^{47}$ This was something I later benefitted from when doing my $\mathrm{PhD}$ research across various police stations in the West Midlands.

While I was an undergraduate, Birmingham (and ex-Birmingham) scholars McConville, Sanders and Leng produced the landmark book, Case for the Prosecution, which illustrated that police discretionary decision-making had not been fettered by legislative changes to police powers. ${ }^{48}$ Roger

46 Allysa J Barrington and Jane Shakespeare-Finch "Working with refugee survivors of torture and trauma: An opportunity for vicarious post-traumatic growth" (2013) 26 Counselling Psychology Quarterly 89; Colin James "Towards trauma-informed legal practice: a review" (2020) 27 Psychiatry, Psychology and Law 275; and Keren Cohen and Paula Collens "The impact of trauma work on trauma workers: A metasynthesis on vicarious trauma and vicarious posttraumatic growth" (2013) 5 Psychological Trauma: Theory, Research, Practice, and Policy 570.

$47 R v$ McIlkenny (1991) 93 Crim App R 287 (Crim app) [The Birmingham Six]. On the impact of the subsequent Royal Commission on Criminal Justice, see Richard Young and Andrew Sanders "Review: The Royal Commission on Criminal Justice: A Confidence Trick?" (1994) 14 Oxford Journal of Legal Studies 435.

48 Andrew Sanders, Michael McConville and Roger Leng The Case for the Prosecution (Routledge, London, 1991). 
Leng, one of the authors of the book, was my criminal law lecturer at the time of its publication, and later became a mentor and friend. Seeing his passion close-up was inspiring.

One of the mainstays of the book is its critique of what it terms the "legal reform model". ${ }^{49}$ While focused on police powers, I would argue that the critique has more general applicability. McConville, Sanders and Leng describe the "seductive and understandable" response of amending legal rules to protect individual defendants and increase the role of victims. ${ }^{50}$ They say: ${ }^{51}$

To advocate reform of this kind implies that social actors are responsive to changes in legal rules and that the response is that which is contemplated by the advocate of reform.

In other words, successful legislative reform requires that the new law does what it was intended, and people using it - or governed by it - change their behaviour accordingly.

While McConville, Sanders and Leng found that changes in legal rules had some impact on the behaviour of actors within the criminal justice process, such changes often produced adaptive behaviour that undermined the intentions of the reform. We cannot rely on law alone as a protective device, otherwise we will slip, say the authors, into a treadmill of permanent law reform in which every failing of the law to deal with certain social behaviours is addressed by a reformulation of the rules. ${ }^{52}$ This may sound familiar to us in New Zealand ...

Although time and criminal justice have moved on, Case for the Prosecution - particularly its critique of the effectiveness of reform of the law itself - remains relevant in two main ways. First, if legal scholarship and reform only looks to legislative amendment, or legal reasoning about a set of established legal norms, we may silo those reforms and the process as a whole, resulting in what has been termed "law without society". ${ }^{53}$ Rule changes need to be mindful of cultural work practices we know that cultural norms in police and the legal profession are not altered easily. ${ }^{54}$

Criminal justice can and should fix the things that are within its own house, but the problems of criminal justice are related to the problems of society as a whole. That means that even reforms that

49 At $191-208$.

50 At 192 .

51 At $192-193$.

52 At 194 .

53 Panu Minkkinen "De Lege Ferenda: What is the 'Socio' of Legal Reasoning?" in Dermot Feenan (ed) Exploring the 'Socio' of Socio-Legal Studies (Palgrave, London, 2013) 85 at 87.

54 Robert Reiner The Politics of the Police (4th ed, Oxford University Press, Oxford, 2010). On organisational inertia generally, see Paul J DiMaggio and Walter W Powell "The Iron Cage Revisited: Institutional Isomorphism and Collective Rationality in Organizational Fields" (1983) 48 American sociological review 147; and on police in particular, see Holly Campeau "Institutional myths and generational boundaries: cultural inertia in the police organisation" (2019) 29 Policing and Society 69. 
attend to criminal justice practice, rather than legal rules, need a broader frame in order to have optimum effect. We cannot make criminal justice "better" without also attending to social deprivation, which both drives and is fed by criminal justice outcomes. The legal reform model does not adequately address inequities and bias. As reform recommendations coming from the Hāpaitia Safe and Effective Justice hui and advisories suggest, we need to both think about what we mean by "law" and also be prepared to look beyond it for ways to make the process better. ${ }^{55}$

Secondly, just as in the 1990s in Britain, New Zealand's current criminal justice process is a place where policy and practice are quasi-legal beasts. In our criminal process, discretionary decisionmaking is common (and necessary). But even putting aside problems with working out how much discretion is required, it can leave the criminal process vulnerable. For example, police adult diversion is a policy that could be withdrawn by Police if they wanted to, even though this would have significant impact for the running of the courts. One might argue that these policies should all be given a legislative base. But the limitations of the legal reform model would remain, as discretion would still be needed, and discretion is notoriously resistant to changes in the law itself. Sexual violence reform offers a good illustrative example. Incremental reform of evidential rules and (to a lesser degree) the substantive law has been a feature of the last 30-plus years. We have instituted many worthwhile reforms, and they have had impact: allowing complainants to give evidence in alternative ways; provision of support persons; controls on questioning, particularly regarding a complainant's previous sexual experience; revising for gender neutrality in the language of the statute; and so on. Yet despite the multitude of reforms, reporting rates remain low, prosecution rates remain low, and conviction rates remain low. ${ }^{56}$ Complainants continue to find the process punishing and rape myths are still prevalent in court. ${ }^{57} \mathrm{We}$ are reaching the end of the road in how much more we can "tinker" with evidential rules and - without major disruption to basic principles - the substantive law. The legal reform model has not worked because, just as McConville, Sanders and Leng identified back in the 1990s, reform to the law itself can only do so much without change to underlying culture and society.

\section{LET'S TRY TO GET WARM: HOW DO WE MAKE CRIMINAL JUSTICE "BETTER"?}

So then, I feel I may have you all feeling quite depressed and despondent at this point. I've argued that the criminal justice process is harmful to everyone within it, and that traditional legal reform is necessary but not sufficient. Do we throw up our hands in despair (do I think I've wasted my time all

55 Various reports and hui playbacks can be found at: "Key Initiatives" (16 July 2021) justice.govt.nz <www.justice.govt.nz>.

56 Ministry of Justice Attrition and progression: Reported sexual violence victimisations in the criminal justice system (November 2019).

57 Tinsley, Baylis and Young "'I Think She's Learnt Her Lesson'", above n 43. 
these years?). We cannot afford to. And in fact, what we know about harms caused by the process and the limitations of the legal reform model can start to illuminate some avenues of potential change, of which I'll mention three here.

The first is one I've been an advocate of using in sexual violence cases for a decade now, but there's no reason why it should be restricted to that type of case. Many of the harms we see come from the nature and operation of the adversarial process. Our modern criminal justice process is young, and if we try to open our eyes to other ways of doing things, we will see that there is no magic to the adversarial trial. It is not a necessary given, and certainly not for all cases. My argument is that we should therefore look to "alternative" processes. What we need is a suite of options, of which the defended trial is but one.

This would work especially well for cases in which there is not enough evidence to bring a prosecution, or where there is sufficient evidence to prosecute, but a prosecution is unlikely to achieve an outcome that addresses the needs of the victim or is in the public interest. In those types of cases right now, harm often goes unaccounted for because the criminal justice process fails to achieve any kind of redress.

Within this suite of options, broadly restorative, therapeutic and educative approaches could operate. That might be within the criminal justice process, and even within the courts. ${ }^{58}$ But the different approaches might also operate outside of the formal process, or as diversion from it. These could include, for example:

- A community problem-solving approach - this would go beyond the current Te Pae Oranga iwi community panels by having support and programmes on hand for victims (and perhaps families) as well as offenders, and being community led and run.

- The provision of educational programmes relevant to the offending.

- A treatment response for the offender.

- A restorative justice type response that would involve a direct or indirect mechanism for the victim to present to the offender the consequences of their conduct and for the offender to acknowledge their wrongdoing and offer redress.

These types of reform would help to locate criminal justice within the broader social justice needs of offenders, victims and communities. It would also allow for communities to have ownership of responses to harm - this could go some way to avoid the problem we often see of co-option of Māori knowledge, experience and political power when devising new programmes. ${ }^{59}$ Care needs to be taken

58 See for example the Te Ao Mārama model introduced in the District Court: Chief District Court Judge "Transformative Te Ao Mārama model announced for District Court" (media release, 11 November 2020).

59 Juan Marcellus Tauri "Restorative justice as a colonial project in the disempowerment of Indigenous peoples" in Theo Gavrielides (ed) Routledge International Handbook of Restorative Justice (Routledge, London, 2018) 342; and Webb, above n 40. 
that those brought within the system in any way are not subjected to more harmful or rights-limiting processes than under the adversarial trial model, an issue that problem-solving courts worldwide have struggled with, for example. ${ }^{60}$

Secondly, real effort should be made to translate high-level recommendations for transformative change into meaningful options for the individual parts of the criminal process as well as looking at the whole. This is a hard job - but without some attempt to see what the reforms would look like for different stages of the process in its niggly detail, we will continue for another 30 years without meaningful change. This effort should show respect for Indigenous knowledge by empowering Māori and other communities, rather than taking place solely within existing policy frameworks.

Thirdly, for cases where we must go to trial, we need to more openly acknowledge the positive role for emotion. Law and emotions research has shown that emotion is not necessarily the antithesis of reason, as lawyers might believe. Of course, poor legal reasoning can and does result from neuroscientific evidence. ${ }^{61}$ However, rather than being the enemies of reason, emotions can and have positively influenced the development of legal reasoning, practice and scholarship. ${ }^{62}$ Neuroscience suggests it is impossible to separate emotion from reason - and we shouldn't try to: emotions pervade, animate and illuminate legal reasoning. ${ }^{63}$ Emotional labour does not have to be negative. Emotions matter for justice.

Recognising the valid role of emotions in decision-making could assist in the courtroom. For example, jurors would benefit from:

- Better emotional as well as factual preparation, including greater emphasis on the benefits of counselling (not just an "offer", but a positive encouragement or expectation); and preparation for the difficulties encountered when undertaking the responsibility of being asked to judge other people's lives.

- More education about group decision-making - some of the stress and pressure jurors endure, as well as inefficiency in deliberations could be ameliorated if jurors had help with how to

60 For criticisms of the harms caused by processes in Alcohol and Other Drug Courts, see Joanne Csete and Denise Tomasini-Joshi Drug Courts: Equivocal Evidence on a Popular Intervention (Open Society Foundations, 2015); and Toni Carr "Governing Addiction: The Alcohol and Other Drug Treatment Court in New Zealand" (PhD thesis, Te Herenga Waka | Victoria University of Wellington, 2020).

61 Tuomas K Pernu and Nadine Elzein "From Neuroscience to Law: Bridging the Gap" (2020) 11 Frontiers in Psychology 1862.

62 Kathryn Abrams and Hila Keren "Who's afraid of law and the emotions" in Susan Bandes (ed) Research Handbook on Law and Emotion (Edward Elgar Publishing, Cheltenham (UK), 2021) 566; and Julia JA Shaw Law and the Passions: Why Emotion Matters for Justice (Routledge, Abingdon (Oxon), 2019).

63 Susan A Bandes and Jeremy A Blumenthal "Emotion and the Law" (2012) 8 Annual Review of Law and Social Science 161. 
go about making a decision. Question trails as a method of jury direction help, but jurors still struggle. ${ }^{64}$

Recognising the validity of emotions can also humanise the criminal justice process, and thereby reduce harm. This example from our research with prosecutors, of a judge humanising their court, shows the difference it can make not just to defendants but to whānau, supporters, lawyers - and probably the judge too!

The judge turned to the gallery... and just said 'does anyone have anything they want to say?' and the defendant stood up and said I'd like to say something. And he [the defendant] pretty much spoke to the family of the victim who died in the gallery and just to ask his friends and family who were there to support him, and he was given the opportunity ... to apologise and to address everyone ... So that was such a lovely thing to happen.

This quote reminds us that we can do better. An approach that recognises everyone's humanity should not be unusual (or worthy of comment in an inaugural lecture). More diversity in the profession, in criminal justice agencies and in academia would be a good start. We have not even touched the tip of the iceberg in finding out more about what Pasifika and Asian communities need in order to be able to adequately access criminal justice. Perhaps a good place to start is to support people from those communities to do that work.

\section{CONCLUSION}

I've thrown down a wee gauntlet this evening for the profession, the academy, politicians and the wider community - for criminal justice reform to work, we need to change our mindsets about the criminal justice process, about emotion and wellbeing within it, and what reform should look like. We won't get anywhere near aspirations like decarceration if we don't! So much more can be done to heal and improve criminal justice - to make it better - and warm up hands and heart.

64 Clough and others, above n 23. 